\title{
o8. Dijital hikâyenin eğitime katkısına dair öğrenci görüşleri
}

Mehtap ÖZDEN' ${ }^{1}$

Engin MEYDAN2

APA: Özden, M.; Meydan, E. (2021). Dijital hikâyenin eğitime katkısına dair öğrenci görüşleri. RumeliDE Dil ve Edebiyat Araştırmaları Dergisi, (23), 122-131. DOI: 10.2900o/rumelide.948307.

\section{$\ddot{\mathbf{O} z}$}

Çalışmada öğrencilerin dijital hikâye kavramı ve dijital hikâyelerin eğitim ve öğretimde kullanılmasına dair görüşleri belirlenmiştir. Nitel araştırma yöntemlerinden durum çalışması kullanılan çalışmanın örneklemi kolay ulaşılabilir örneklem tekniğiyle seçilmiş ve veriler "Dïital hikâyeler ve eğitimde kullanılması" adlı görüşme formu ile toplanmıştır. Öğrenciler; dijital hikâye kavramı hakkında olumlu kategoride \% 80.76 oranında ve altı farklı kodda; olumsuz kategoride ise \% 19.23 oranında ve iki farklı kodda görüş bildirmiştir. Dijital hikâye kavramı hakkındaki bilgilerinin en çok dijital ortam ve hikâyenin birleşmesi şeklinde (\% 39.58) olduğu ve tam anlamıyla dijital hikâye kavramını bilen öğrencilerin oranının (\% 2,3) düşük olduğu belirlenmiştir. Dijital hikâyelerin öğrenmede bilgi ve becerileri kazandıracağına öğrencilerin olumlu baktığı (evet \% 67, 94), bu olumlu bakışın öğrenim seviyesi açısından değerlendirildiğinde ön lisans \% 52,5, lisans \% 72,72 ve lisansüstü \% 100 şeklinde olduğu görülmüştür. Dijital hikâyelerin öğrenmeye katkısı konusunda verilen dokuz kod en çok "Katılıyorum” kategorisinde "anlama \% 55.81, değer kazanımı \% 45.34, ders başarısı sağlama \% 44.18, esnek öğretim ortamı \% 48.83, kalıcı öğrenme sağlama \% 34.88 , memnuniyet \% 51.16, özgüveni yükseltme \% 38.37, somut deneyimler elde etme \% 44.18, üretici kılma \% 51.16” değerlendirilmiştir. Sonuçta öğrencilerin dijital hikâyeler hakkında tam bir bilgiye sahip olmasalar da öğrenmeye katkısı olacağı görüşünde oldukları belirlenmiştir.

Anahtar kelimeler: Dijital hikâye, dijital hikâyelerin eğitim ve öğretimde kullanılması, öğrenci görüşleri

\section{The digital story's contribution to education}

\begin{abstract}
In the study, students' views on the concept of digital stories and the use of digital stories in education and training were determined. The sample of the study, in which case study was used as one of the qualitative research methods, was selected with an easily accessible sampling technique, and the data were collected with an interview form called "Digital stories and their use in education". Students; $80.76 \%$ of the digital story concept in the positive category and in six different codes; In the negative category, $19.23 \%$ of the opinions expressed in two different codes. It was determined that their knowledge about the concept of digital stories was mostly in the form of the combination of digital media and story (39.58\%) and the rate of students who fully knew the concept of digital stories (2.3\%) was low. It was observed that the students were positive (yes,
\end{abstract}

Doç. Dr., Çanakkale Onsekiz Mart Üniversitesi, Eğitim Fakültesi, Türkçe ve Sosyal Bilimler Eğitimi, Türkçe Eğitimi ABD (Çanakkale, Türkiye), mehtapgunes@comu.edu.tr, ORCID ID: oooo-0oo3-0385-5744 [Araştırma makalesi, Makale kaylt tarihi: 28.04.2021-kabul tarihi: 20.06.2021; DOI: 10.29000/rumelide.948307] Dr. Öğr. Üyesi, Çanakkale Onsekiz Mart Üniversitesi, Ezine Meslek Yüksekokulu (Çanakkale, Türkiye), enginmeydan@comu.edu.tr, ORCID ID: 0000-0002-1860-1715

\section{Adres $\mid$ Address}

RumeliDE Dil ve Edebiyat Araşttrmaları Dergisi Osmanağa Mahallesi, Mürver Çiçeği Sokak, No:14/8 Kadıköy - İSTANBUL / TÜRKIYE 34714 e-posta: editor@rumelide.com tel: +90 $5057958124,+902167730616$
RumeliDE Journal of Language and Literature Studies Osmanağa Mahallesi, Mürver Çiçeği Sokak, No:14/8

Kadıköy - ISTANBUL / TURKEY 34714

e-mail: editor@rumelide.com,

phone: +90 $5057958124,+902167730616$ 
67.94\%) that digital stories would add knowledge and skills in learning, and this positive view was found to be $52.5 \%$ for associate degree, $72.72 \%$ for undergraduate and $100 \%$ for graduate degrees when evaluated in terms of education level. The nine codes given about the contribution of digital stories to learning are mostly in the category of "I agree" $55.81 \%$, gaining value $45.34 \%$, achieving course success $44.18 \%$, flexible teaching environment $48.83 \%$, providing permanent learning $34.88 \%$, satisfaction $51.16 \%$, increasing self-confidence $38.37 \% .44 .18 \%$ to obtain concrete experiences, $51.16 \%$ to make productive. As a result, it was determined that although the students do not have complete information about digital stories, they think that they will contribute to learning.

Keywords: Digital story, use of digital stories in education and training, student views

\section{Giriş}

Dijitalleşme 21. yüzyılda hayatın her alanına girmiş ve bu değişimden eğitim ve öğretim ortamları da nasibini almış ve almaya devam etmektedir. Hikâye veya hikâyeleştirme insanoğlunun var olduğu ilk zamanlardan günümüze kadar devam eden ve bundan sonra da devam edecek bir anlatım biçimidir. İnsan, kendisini anlatma ihtiyacını var olduğu ilk günden itibaren duymaktadır. Kendisini ifade etmek, isteklerini, ihtiyaçları vs. çevresindekilere aktarmak için anlatım teknikleri olarak konuşma ve yazmayı kullanır. Konuşurken de yazarken de en kolay ve en akılda kalıcı anlatım tekniği hikâyeleştirmedir. Lambert ve Hessler (2013) hikâyeleri öncelikle deneyimlerimizle bildiğimizi ancak bize anlatılan hikâyelerin kabilemizin, topluluğumuzun, kültürümüzün bir parçası olduğunu ve efsanevi bir modelleme olarak kafamızda şekillendiğini ifade etmektedir. Yolculuğun, romantizmin, gizemin hikâyelerinde kendi hayatlarımızı, kimliğimizi ve en önemli ilişkilerimizi kahramanın, sevgilinin, arayanın, büyücünün, yardımcının, canavarın karakterlerinde gördüğümüzü anlatmaktadırlar. Hikâyeleştirerek olaylar ve olgular belli bir sıraya konulur. Bu sıralama anlatılanların kolay ifade edilmesine ve anlaşılmasına etki eder. Bu sebeple hikâyeleştirilerek anlatılan her şeyin daha fazla akılda kalıcı olacağı ve daha rahat bir şekilde de aktarılacağı uzun yıllardır bilinen bir gerçektir. En eski zamanlardan itibaren masal, destan, fabl ve hikâyelerin bireylerin eğitiminde ve öğretim faaliyetlerinde yararlanıldığı bilinen bir gerçektir. Bu tür metinler görseller, sesler vb. desteklendiğinde akılda kalıcılığı ve iletilmek istenen mesajın ulaştırılması çok daha kolay ve etkili olmaktadır. Bu özelliklerin dijital ortamda hazırlanan materyallerde de olması mümkündür ve bu sebeple dijital ortamda hazırlanan hikâyelerin hedef kitleye ulaşması hem daha etkili hem de daha kolay olacaktır.

Hikâye anlatma geleneği binlerce yıldır devam eden bir gelenektir. "Antik çă̆ insanlarının eğlenmek, hoş vakit geçirmek, gençlere hayat tecrübelerini, dinî ve kültürel mirası aktarmak amacıyla hikâye anlatma sanatının oluştuğunu böylelikle, edebiyatın ortaya çıtığını söylemek mümkündür” (Russell, 2004, 3). Konuşma becerisinde başarılı olan bireylerin kimi zaman profesyonel bir meslek olarak bile icra ettiği hikâye anlatılıcılığı 21. yüzyılda dijital hikâye anlatıcılı̆̆ı şekline dönüşmektedir denilebilir. Dijital hikâye anlatıcılı̆̆ının kökenine bakıldığında 1990'lı yıllar ve Amerika dikkati çekmektedir. "1990'lara gelindiğinde, hikâye anlatımını geliştirmek için bir grup medya sanatçısı ve tasarımcısı bir araya gelmiştir. Bir medya yapımcısı ve disiplinler arası sanatçı olan Dana Atchley ve tiyatro yönetmeni Joe Lambert'in birlikte çalışmaları, çoklu ortam ile hiç deneyimi olmayan bireylerin bile kişisel hikâyelerini yeni teknolojiler ile dijitalleştirebileceğini ortaya çıkarmıştır. 1994’te Joe Lambert, Dana Atchley ve Nina Mullen bir araya gelerek San Fransisco'da Dijital Medya Merkezini kurmuşlardır. 1998'de Merkez, California'da Berkeley'a taşınarak Dijital Hikâye Anlatımı Merkezi (Center for Digital Storytelling - CDS) olmuştur. 2015'ten buyana ise merkez, Hikâye Merkezi (Story

\footnotetext{
\begin{tabular}{r|l} 
Adres & Address \\
RumeliDE Dil ve Edebiyat Araşttrmalart Dergisi & RumeliDE Journal of Language and Literature Studies
\end{tabular} Osmanağa Mahallesi, Mürver Çiçeği Sokak, No:14/8 Osmanağa Mahallesi, Mürver Çiçeği Sokak, No:14/8 Kadıköy - İSTANBUL / TÜRKIYE 34714 Kadıköy - ISTANBUL / TURKEY 34714 e-posta: editor@rumelide.com e-mail: editor@rumelide.com, tel: +90 505 7958124, +90 2167730616 phone: +90 505 7958124, +90 2167730616
} 
Center) ismi ile devam etmektedir" (Çıralı Sarıca, 2019, 23). Bugün gelinen noktada gelişen medya teknolojileri dijital hikâye anlatıcılığının da gelişmesine ve çeşitli alanlarda kullanılmasına sebep olmaktadır.

Kearney (2011); dijital hikâyeleri videolar, resimler/fotoğraflar, sesli veya yazılı anlatımlar ve müzikle oluşturulan sanat yönü olan, kuvvetli duygusal içeriğe sahip çekimler olarak ifade etmektedir. Dijital hikâye anlatıcılığının başlangıcı Amerika'da gerçekleştirilen bir gösteri olarak bilinmektedir. "Gelişmiş medya teknolojilerinin kullanılarak hikâye anlatılmaya başlanmasının 1990'larda Amerika Birleşik Devletleri'nde Kaliforniya Berkley'de Dana Atchley ve Joe Lambert'in deneysel performansı Next Exit yer almaktadır" (Şimşek, Usluel, Çıralı Sarıca ve Tekeli, 2018, 5).

Dijital hikâyenin bilgisayar çağında yaşayan akademisyenler ve uzmanlar için önemi yadsınamaz, ayrıca dijital hikâyeler oluşturma konusunda öğrencilerden toplumun başka pek çok kesimine kadar verilecek eğitimlerle bireylerin kendilerini ifade etmeleri de sağlanabilir. Yapay zekâ ve eğitimle ilgilenen Schank (1995) insan zekâsını anlamak ve bu yolla yapay zekâyı açıklamayı hikâyeler aracılı̆̆ı ile yapmıştır. Schank Tell Me a Story (1995) kitabında zekâ ve hikâye anlatma sürecini; "hikâyelerde bilgi, hikâyeler nereden geliyor ve neden onlara anlatıyoruz? Diğer insanların hikâyelerini anlamak, hikâyeleri indeksleme, hafızayı şekillendirmek, kültürünün hikâyelerini bilmek, hikâyeler ve zekâ" başlıkları altında anlatmıştır. 21. yüzyılda bilişsel düşünme becerilerinin geliştirilmesinde dijital hikâye oluşturmanın faydaları açıktır. "Dijital hikâye anlatımı öz yönlendirme ve bireysel inisiyatifi desteklerken aynı zamanda yaratıcılı̆̆ ve sorun çözme becerisini de geliştirir” (McLellan, 2006, s. 68). İnsanlar daima gayri resmi olarak hikâyeler anlatır ve bunu resmî olarak yapmak da mümkündür. Bireysel gelişme, yaratıcılık ve sorunların çözümünde dijital hikâyeleri kullanmak faydalı olabilir.

Türkiye'de dijital hikâyelerle ilgili çalışmalara bakıldığında 200o'li yıllarda çalışmaların başladığı söylenebilir. Türkiye'de dijital hikâyeciliğin geliştirilmesi için araştırmacılar çeşitli öneriler ileri sürmektedir. "DHA kavramının dünyada yeni medya teknolojilerinin kullanıldığı her türlü hikâye anlatma pratiğine gönderme yapan formunun, Türkiye'de yeni medya hikâyeciliği olarak ayrışmasını akılda tutarak, yeni adıyla Hikâye Merkezi (Story Center) daha öncelerdeki adıyla ise DHA Merkezi'nin yaygınlaştırdığı formun atölye temelli, gerçek hayattan bir deneyim kesitini hikâyeleştirmeye ve bunu dijital teknolojiler yoluyla paylaşlabilir hale getirmeyi hedefleyen bir uygulama olduğuna dikkat çekmenin gereği ortadadır" (Şimşek, Usluel, Çıralı Sarıca ve Tekeli, 2018, 21). Türkiye'de dijital hikâye ile ilgili çalışmalar iletişim ve bilgisayar teknolojileri ile ilgili araştırmacılarca başlatılmıştır. Dijital hikâye oluşturma başlangıçta toplumsal bir hareketin yansıtılmasında kullanılan araç olarak görülmüştür. "DHA hareketi, gücünü dayanışmacı hikâye anlatma, hikâye etme pratiklerinden almış ve farklı bir yetkinlik ve okuryazarlık düzeyi gerektiren yazı ile profesyonelleşen ilişkinin karşısına deneyimi önceleyen, sözlü kültürde köklenen daha deneysel bir pratiği yerleştirmiştir. Nitekim Türkiye'de Şimşek (2012), özellikle feminist sivil toplum örgütleriyle düzenlenen DHA atölyeleri deneyimi üstünden, ses ve söz hattındaki hikâye anlatma pratikleri ile yazı ve okuryazarlık hattında örgütlenen öykü yazma pratikleri arasındaki ayrışmaya dikkat çekmiştir" (Şimşek, Usluel, Çıralı Sarıca ve Tekeli, 2018, 6).

Dijital hikâye; okulda öğretiminde güçlük yaşanan pek çok ders içeriğinin öğrencilere öğretiminde etkili olabilir. Dili doğru ve etkili kullanma, farklı duyulara yönelik materyaller, doğru iletişim yöntemleriyle yapılacak öğretim süreci eğitimde yaşanılan pek çok sorunun çözümü olabilir. Dijital hikâyeler yoluyla bir bilgiyi, düşünceyi veya iddiayı vb. açıklamak hatta yeri geldiğinde savunmak mümkün olabilir. Birçok sebepten dolayı yaygınlaşan uzaktan eğitim faaliyetlerinde dijital hikâyelerin

Adres Address

RumeliDE Dil ve Edebiyat Araşttrmalar Dergisi $\quad$ RumeliDE Journal of Language and Literature Studies Osmanağa Mahallesi, Mürver Çiçeği Sokak, No:14/8 Osmanağa Mahallesi, Mürver Çiçeği Sokak, No:14/8 Kadıköy - İSTANBUL / TÜRKIYE 34714 Kadıköy - ISTANBUL / TURKEY 34714 e-posta: editor@rumelide.com e-mail: editor@rumelide.com, tel: +90 505 7958124, +90 2167730616 phone: +90 505 7958124, +90 2167730616 
etkili birer materyal olarak kullanılması da mümkündür. Dijital hikâyeler ayrıca sınıf içinde yapılacak çalışmalardan, öğretmenlerin mesleki yeterliliklerine varana kadar pek çok çalışmaya, iletişim becerilerinin, üstbilişsel farkındalığın ve bilimsel okuryazarlığın gelişiminde etkilidir. Dijital hikâye anlatımında genellikle otobiyografiler fikir ve güçlü bir duygu uyandırmak için kısa ve öz şekilde kullanır. Akademisyenler gelişmekte olan teknolojilere daha aşina hale geldikçe öğrenciler tarafından oluşturulacak bu tür materyallerin daha fazla ilgi görmesi beklenmektedir” (Kearney, 2011, 184). Günümüzde dijital dünyanın ve hikâye türünün olanaklarından yararlanmak, bu yolla etkili öğretim materyalleri geliştirmek ve kullanmak öğretime katkı sağlayacaktır. Böylece öğretmenler daha etkili öğretim faaliyetleri ile öğrenciler ise daha etkili öğrenim faaliyetleri ile karşılaşacaktır.

\section{Araştırmanın amacı}

Çalışma değişen ve gelişen eğitim ortamlarında ortaya çlkan ihtiyaçlara yönelik olarak neler yapılabileceği fikrinden doğmuştur. Araştırmada ön lisans, lisans ve lisansüstü seviyede öğrenim gören öğrencilerin dijital hikâyeler ve eğitimde kullanılması konusunda farkındalık düzeylerini belirlemek amaçlanmıştır. Araştırmada aşağıdaki sorulara cevap aranmıştır:

1. Ön lisans, lisans ve lisansüstü öğrencilerine dijital hikâye kavramı ne ifade etmektedir?

2. Ön lisans, lisans ve lisansüstü öğrencilerine göre dijital hikâyeler eğitim ve öğretimde çeşitli bilgi ve becerilerin kazandırılması-geliştirilmesine katkı sağlar mı?

3. Ön lisans, lisans ve lisansüstü öğrencilerinin dijital hikâyelerin öğrenmeye katkısı ile ilgili düşünceleri nelerdir?

\section{Yöntem}

Çalışma dijital hikâyeler ve eğitimde kullanılmasına ilişkin öğrencilerin görüşlerini belirlemeyi amaçlayan nitel bir çalışmadır ve var olan durumu saptamaya yönelik olduğu için nitel araştırma tekniklerinden yola çıkılarak desenlenmiştir. "Durum çalışması; tek bir durum ya da olayın derinlemesine boylamsal olarak incelendiği, verilerin sistematik bir şekilde toplandığı ve gerçek ortamda neler olduğuna bakıldığı bir yöntemdir" (Subaşı ve Okumuş, 2017, 420). Çalışmada nitel araştırma yöntemlerinden durum çalışması kullanılmıştır.

\section{Katılımcılar}

Çalışmada katılımcılar veri kaynağı çeşitlemesi yapılmak amaçlandı ̆̆ı için ön lisans, lisans ve lisansüstü öğrencilerden seçilmiştir. "Farklı veri kaynă̆ı çeşitlemesi, farklı katılımcılardan (öğretmen, yönetici, veli ve öğrenci vb.) elde edilen verilerin birbiriyle tutarlı olmasıyla ilgilidir" (Saban ve Ersoy, 2017, 161). Çalışmanın örneklemi; amaçlı örneklem yöntemine göre seçilmiş 89 gönüllü ön lisans, lisans ve lisansüstü öğrenciden oluşmaktadır. Çalışmaya 40 ön lisans, 22 lisans ve 16 lisansüstü öğrenci katılmıştır. Çalışmada verileri toplamak amacıyla gönderilen görüşme formuna 89 öğrenciden cevap gelmiş ve çalışmaya gönüllü olarak katılacaklarını beyan etmişlerdir. Ancak bu öğrencilerden 78'i "Dijital hikâye kavramı ne ifade etmektedir?" ve "Dijital hikâyelerin eğitim ve öğretimde çeşitli bilgi ve becerilerin kazandırılması-geliştirilmesine katkısı hakkındaki düşünceleriniz nelerdir?” sorularına cevap vermiştir. Çalışmaya katılmayı kabul ettiğini beyan eden 89 öğrenciden 86’sı da kapalı uçlu sorulardan oluşan "Dijital hikâyelerin öğrenmeye katkısı hakkındaki düşünceleriniz

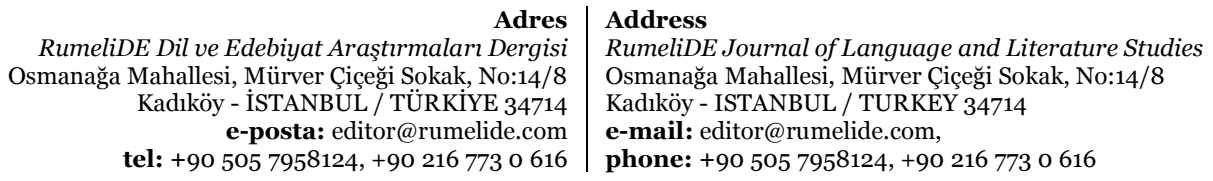


nelerdir?” bölümündeki sorulara cevap vermiştir. Bu durum sebebiyle çalışmada elde edilen verilerde yarı yapılandırılmış sorularla yapılandırılmış sorular arasında farklılık bulunmaktadır.

Tablo 1.Öğrencilerin öğrenim durumlarına göre cinsiyetleri

\begin{tabular}{lllllllll}
\hline & Ön lisans & & Lisans & \multicolumn{3}{c}{ Yüksek lisans } & \multicolumn{2}{c}{ Toplam } \\
& F & \% & F & \% & F & \% & F & \% \\
K1z & 24 & 60 & 13 & 59,09 & 9 & 56,25 & 46 & 58,97 \\
Erkek & 16 & 40 & 9 & 40,9 & 7 & 43,75 & 32 & 41,02 \\
Toplam & 40 & 100 & 22 & 100 & 16 & 100 & 78 & 100 \\
\hline
\end{tabular}

Tablo 1'de de görüldüğü gibi çalışmaya katılan öğrencilerin \% 58.97'si kı, \% 41.02'si erkek öğrencilerden meydana gelmiştir.

Tablo 2. Öğrencilerin öğrenim durumları

\begin{tabular}{lll}
\hline Ön lisans & F & $\%$ \\
Lisans & 40 & 51.28 \\
Yüksek lisans & 22 & 28.2 \\
Toplam & 16 & 20.51 \\
\hline
\end{tabular}

Tablo 2'de de görüldüğü gibi çalışmaya katılan öğrencilerin \% 51,28'i ön lisans, \% 28,2'si lisans ve \% 20,51' yüksek lisans öğrencilerinden meydana gelmiştir.

\section{Verilerin toplanması}

Veriler "Dijital hikâyeler ve eğitimde kullanılması" adlı görüşme formu ile toplanmıştır. Formda öğrencilerin demografik bilgileri ve araştırmacılar tarafından hazırlanan 2 açık uçlu ve 12 kapalı uçlu soru yer almıştır. Kapalı uçlu sorularda öğrencilerin dijital hikâyelerin öğrenmeye katkısı hakkındaki düşüncelerinin neler olabileceği alan yazın taraması ile belirlenmiş ve belirlenen muhtemel cevaplar beşli derecelendirme ile öğrencilere sunulmuştur. Veriler; Covid-19 salgını sebebiyle Google Formlar aracılığı ile katılımcılara ulaştırılmıştır.

\section{Verilerin analizi}

Çalışmada toplanılan verilerin analizinde betimsel analiz ve içerik analizi kullanılmıştır. Öğrencilerin demografik özelliklerini belirlemek için kullanılan bilgiler betimsel, görüşme formlarından elde edilen veriler ise içerik analizi kullanılarak çözümlenmiştir. Araştırmanın güvenirliğini sağlamak amacıyla verilerin içerik analizi aşamasında iki araştırmacı tarafından veriler kodlandıktan sonra karşılıklı olarak veri kontrolü yapmıştır. Miles ve Huberman (1994) tarafından sosyal olguların anlaşılması için ortaya konulan Miles ve Huberman Modeli verilerin azaltılması, verilerin sunulması ve sonuçların biçimlendirilmesi aşamalarından oluşmaktadır ve araştırmada bu modelden yola çıkılarak veriler değerlendirilmiştir. Verilerin güvenirliğinde Miles ve Huberman'ın (1994) güvenirlik formülü kullanılarak Güvenirlik=Görüş Birliği/(Görüş Birliği+Görüş Ayrılığı) kodlayıcılar arası görüş birliği o.81 bulunmuştur. Bu da kodlama aşamasında çalışmanın güvenilir olduğunu ortaya koymaktadır.

\begin{tabular}{r|l} 
Adres & Address \\
RumeliDE Dil ve Edebiyat Araşttrmalar Dergisi & RumeliDE Journal of Language and Literature Studies \\
Osmanağa Mahallesi, Mürver Çiçeği Sokak, No:14/8 & Osmanağa Mahallesi, Mürver Çiçeği Sokak, No:14/8 \\
Kadıköy - İSTANBUL / TÜRKIYE 34714 & Kadıköy - ISTANBUL / TURKEY 34714 \\
e-posta: editor@rumelide.com & e-mail: editor@rumelide.com, \\
phone: +90 505 7958124, +90 2167730616
\end{tabular}




\section{Bulgular}

Bu bölümde dijital hikâye kavramı, dijital hikâyelerin eğitim ve öğretimde çeşitli bilgi ve becerilerin kazandırılması-geliştirilmesine katkısı ve dijital hikâyelerin öğrenmeye katkıları hakkında öğrencilerin görüşlerinden yola çıkılarak elde edilen veriler yer almaktadır.

Öğrencilerle dijital hikâye kavramı konusunda yapılan görüşmeler sonucunda elde edilen kategoriler ve bu kategorilere ait kodlar Tablo 3’te verilmiştir.

Tablo 3. Öğrencilerin dijital hikâye kavramı hakkındaki düşünceleri

\begin{tabular}{|c|c|c|c|c|c|}
\hline Kategoriler & Kodlar & & & & \\
\hline \multirow{7}{*}{ Olumlu } & Kod & $\mathbf{f}$ & $\%$ & \multicolumn{2}{|c|}{ Toplam } \\
\hline & İnternet aracilığı ile sunulan olaylar ve yazılar & 34 & $43 \cdot 58$ & \multirow{6}{*}{63} & \multirow{6}{*}{80.76} \\
\hline & Teknolojik gelişmeleri metinlere uygulayabilme & 9 & 11,53 & & \\
\hline & Ekran üzerinden okunabilen e kitap şeklinde yazı & 8 & 10,25 & & \\
\hline & Bir nevi bilgi ve anlatımın birleşimi & 7 & $\mathbf{8 , 9 7}$ & & \\
\hline & Kolayllk & 3 & $\mathbf{3}, \mathbf{8 4}$ & & \\
\hline & Bir öykü anlatımcısını 3-5 dakika kendi sesiyle anlattığı kısa bir film & $\underline{\mathbf{2}}$ & $\mathbf{2 , 5 6}$ & & \\
\hline \multirow{3}{*}{ Olumsuz } & Bilmiyorum, anlamadım & 11 & 14,10 & & \\
\hline & Faydasız/ Saçma & 4 & 5,12 & 15 & 19.23 \\
\hline & Toplam & 78 & 100 & 78 & 100 \\
\hline
\end{tabular}

Tablo 3 incelendiğinde öğrencilerin dijital hikâye kavramı hakkında düşüncelerinin olumlu ve olumsuz kategorilerden oluştuğu görülmektedir. Olumlu kategoride toplanan düşünceler \% 68 oranında ve altı alt kodda, olumsuz kategoride toplanan düşünceler ise \% 17.94 oranında ve iki alt kodda toplanmıştır. Olumlu kategorisinden elde edilen kodlamalardan araştırmaya katılan öğrencilerin \% 43,58'i dijital hikâye kavramını sanal ortamda daha önce var olan hikâyelerin yer alması, \% 10,25’i teknolojik ve yeni olgular, \% 8,97'si daha iyi anlama aracı, \% 3,84'ü kolaylık, faydalı vb., \% 2,56'sı kendi sesiyle anlattığı kısa bir film şeklinde kısaca ifade edilebilecek tanımlamışlardır. Olumsuz kategorisinden elde edilen kodlamalardan araştırmaya katılan öğrencilerin \%14,10’u dijital hikâyeler hakkında bilgisi olmadığını, \% 5,12'si dijital hikâyeleri faydasız veya gereksiz bulmuş, öğrencilerin \% 5,12'si bu tür bir öğrenme aracına faydasız gözüyle bakmış, \% 14,10’u bilgi sahibi olmadığını söylemiştir. Öğrencilerin yaklaşık \% 8o’i ise dijital hikâye kavramı hakkında olumlu görüş bildirmişlerdir.

Tablo. 4. Öğrencilerin dijital hikâyelerin eğitim ve öğretimde ç̧şitli bilgi ve becerilerin kazandırılmasıgeliştirilmesine katkısı hakkındaki düşünceleri

\begin{tabular}{lllllllll}
\hline & \multicolumn{2}{c}{ Ön lisans } & \multicolumn{2}{c}{ Lisans } & \multicolumn{2}{c}{ Yüksek lisans } & \multicolumn{2}{c}{ Toplam } \\
& f & $\mathbf{\%}$ & $\mathbf{f}$ & $\mathbf{\%}$ & $\mathbf{f}$ & $\mathbf{\%}$ & f & \% \\
\hline Evet & 21 & 52,5 & 16 & 72,72 & 16 & 100 & 53 & 67.94 \\
Kismen & 9 & 22,5 & 4 & 18,18 & - & - & 13 & 16.66 \\
Fikrim yok & 9 & 22,5 & - & - & - & - & 9 & 11.53 \\
Hayır & 1 & 2,5 & 2 & 9,09 & - & - & 3 & 3.84 \\
Toplam & 40 & 100 & 22 & 100 & 16 & 100 & 78 & 100 \\
\hline
\end{tabular}

\begin{tabular}{r|l} 
Adres & $\begin{array}{l}\text { Address } \\
\text { RumeliDE Dil ve Edebiyat Araşturmaları Dergisi }\end{array}$ \\
RumeliDE Journal of Language and Literature Studies \\
Osmanağa Mahallesi, Mürver Çiçeği Sokak, No:14/8 & Osmanağa Mahallesi, Mürver Çiçeği Sokak, No:14/8 \\
Kadıköy - İSTANBUL / TÜRKIYE 34714 & Kadıköy - ISTANBUL / TURKEY 34714 \\
e-posta: editor@rumelide.com & $\begin{array}{l}\text { e-mail: editor@rumelide.com, } \\
\text { phone: +90 505 7958124, +90 } 216773 \text { o } 616\end{array}$ \\
tel: +90 505 7958124, +90 216 773 o 616 &
\end{tabular}


Tablo 4’te öğrencilerin dijital hikâyelerin eğitim ve öğretim faaliyetlerinde kullanılabilirliği ile görüşlerine bakıldığında \% 67,94’ü evet cevabı vererek dijital hikâyelerin eğitim ve öğretimde kullanılmasını olumlu bulduklarını ifade etmişlerdir. Öğrencilerin \% 3,84’ü ise dijital hikâyelerin eğitim ve öğretimde kullanılmaması gerektiği yönünde görüş bildirmişlerdir. Öğrencilerin \% 11,53’ü konu hakkında fikri olmadığını \%16,66'sı ise bu tür materyallerin kısmen eğitim ve öğretimde kullanılabileceğini söylemişlerdir. Öğrenim durumlarına göre bakıldığında ise ön lisans öğrencilerinin \% 52,5'nin evet, \% 22,5'nin kısmen diyerek dijital hikâyelerin eğitimde kullanılmasına olumlu baktıkları anlaşılmıştır. Ön lisans öğrencilerinin \% 22,5’i konu hakkında fikri olmadığını, \% 2,5’i ise dijital hikâyelerin eğitimde kullanılmasının mümkün olmadığını söylemişlerdir. Lisans öğrencilerine gelindiğinde öğrencilerin \% 72,72'sinin evet, \% 18,8'inin kısmen diyerek dijital hikâyelerin eğitimde kullanılmasına olumlu baktıkları görülmektedir. Lisans öğrencilerinin \% 9,og'unun ise dijital hikâyelerin eğitimde kullanılmaması gerektiği düşüncesinde olduğu anlaşılmıştır. Yüksek lisans öğrencileri ise \% 100 oranında dijital hikâyelerin eğitimde kullanılmasının faydalı olacağı görüşündedir.

Tablo 5 'te öğrencilerin dijital hikâyelerin öğrenmeye katkısı ile ilgili düşüncelerine verilen cevaplar yer almaktadir.

Tablo 5. Öğrencilerin dijital hikâyelerin öğrenmeye katkısı ile ilgili düşünceleri

\begin{tabular}{|c|c|c|c|c|c|c|c|c|c|c|c|c|}
\hline \multirow[b]{3}{*}{ Anlama } & \multicolumn{2}{|c|}{$\begin{array}{l}\text { Kesinlikle } \\
\text { katılıyoru } \\
\text { m }\end{array}$} & \multicolumn{2}{|c|}{$\begin{array}{l}\text { Katıliyoru } \\
\text { m }\end{array}$} & \multicolumn{2}{|c|}{$\begin{array}{l}\text { Kismen } \\
\text { katıliyoru } \\
\text { m }\end{array}$} & \multicolumn{2}{|c|}{$\begin{array}{l}\text { Katılmiyoru } \\
\text { m }\end{array}$} & \multicolumn{2}{|c|}{$\begin{array}{l}\text { Kesinlikle } \\
\text { katılmıyoru } \\
\text { m }\end{array}$} & \multicolumn{2}{|c|}{ Toplam } \\
\hline & $\mathrm{F}$ & $\%$ & $\mathrm{~F}$ & $\%$ & $\mathrm{~F}$ & $\%$ & $\mathrm{~F}$ & $\%$ & $\mathrm{~F}$ & $\%$ & $\mathrm{~F}$ & $\%$ \\
\hline & 24 & 27.9 & 48 & 55.81 & 10 & 11.62 & 4 & 4,65 & - & - & $\begin{array}{l}8 \\
6\end{array}$ & $\begin{array}{l}10 \\
0\end{array}$ \\
\hline $\begin{array}{l}\text { Değer } \\
\text { kazanımı }\end{array}$ & 21 & 24.41 & 39 & $45 \cdot 34$ & 23 & 26.74 & 3 & 3,48 & - & - & $\begin{array}{l}8 \\
6\end{array}$ & $\begin{array}{l}10 \\
0\end{array}$ \\
\hline $\begin{array}{l}\text { Ders } \\
\text { başarısı } \\
\text { sağlama }\end{array}$ & 23 & 26.7 & 38 & 44.18 & 21 & 24.41 & 3 & 3,48 & 1 & 1,16 & $\begin{array}{l}8 \\
6\end{array}$ & $\begin{array}{l}10 \\
0\end{array}$ \\
\hline $\begin{array}{l}\text { Esnek } \\
\text { öğretim } \\
\text { ortamı }\end{array}$ & 24 & 27.9 & 42 & 48.83 & 17 & 19.76 & 3 & 3,48 & - & - & $\begin{array}{l}8 \\
6\end{array}$ & $\begin{array}{l}10 \\
0\end{array}$ \\
\hline $\begin{array}{l}\text { Kalıcı } \\
\text { öğrenme } \\
\text { sağlama }\end{array}$ & 26 & 30.2 & 30 & 34.88 & 21 & 24.41 & 7 & 8,13 & 2 & 2,32 & $\begin{array}{l}8 \\
6\end{array}$ & $\begin{array}{l}10 \\
0\end{array}$ \\
\hline $\begin{array}{l}\text { Memnuniye } \\
t\end{array}$ & 25 & 29.06 & 44 & 51.16 & 11 & 12.79 & 3 & 3,48 & 3 & 3,48 & $\begin{array}{l}8 \\
6\end{array}$ & $\begin{array}{l}10 \\
0\end{array}$ \\
\hline $\begin{array}{l}\text { Özgüveni } \\
\text { yükseltme }\end{array}$ & 22 & $25 \cdot 58$ & 33 & 38.37 & 18 & 20,93 & 10 & 11,62 & 3 & 3,48 & $\begin{array}{l}8 \\
6\end{array}$ & $\begin{array}{l}10 \\
0\end{array}$ \\
\hline $\begin{array}{l}\text { Somut } \\
\text { deneyimler } \\
\text { elde etme }\end{array}$ & 24 & 27.9 & 38 & 44.18 & 17 & 19,76 & 4 & 4,65 & 3 & 3,48 & $\begin{array}{l}8 \\
6\end{array}$ & $\begin{array}{l}10 \\
0\end{array}$ \\
\hline $\begin{array}{l}\text { Üretici } \\
\text { kılma }\end{array}$ & 19 & 19.76 & 44 & 51.16 & 17 & 19,76 & 5 & 5,81 & 1 & 1,16 & $\begin{array}{l}8 \\
6\end{array}$ & $\begin{array}{l}10 \\
0\end{array}$ \\
\hline
\end{tabular}

Öğrencilere dijital hikâyelerin öğrenmeye katkısı ile ilgili olarak "Kesinlikle katılıyorum, Katılıyorum, Kısmen katılyyorum, Katılmıyorum ve Kesinlikle katılmıyorum" kategorileri ve "Anlama, Değer kazanımı, Ders başarısı sağlama, Esnek öğretim ortamı, Kahıcı öğrenme sağlama, Memnuniyet,

\begin{tabular}{r|l} 
Adres & Address \\
RumeliDE Dil ve Edebiyat Araşttrmalar Dergisi & RumeliDE Journal of Language and Literature Studies \\
Osmanağa Mahallesi, Mürver Çiçeği Sokak, No:14/8 & Osmanağa Mahallesi, Mürver Çiçeği Sokak, No:14/8 \\
Kadıköy - İSTANBUL / TÜRKIYE 34714 & Kadıköy - ISTANBUL / TURKEY 34714 \\
e-posta: editor@rumelide.com & e-mail: editor@rumelide.com, \\
phone: +90 505 7958124, +90 2167730616
\end{tabular}


Özgüveni yükseltme, Somut deneyimler elde etme ve Üretici kllma” kodları sunulmuştur. Tablo 5’te öğrencilerin dijital hikâyelerin öğrenmeye katkısı konusunda görüşme formunda verilen dokuz kodu da en çok "Katılıyorum" kategorisinde gördükleri anlaşılmaktadır. Anlama \% 55.81, değer kazanımı \% 45.34, ders başarısı sağlama \% 44.18, esnek öğretim ortamı \% 48.83, kalıcı öğrenme sağlama \% 34.88, memnuniyet \% 51.16, özgüveni yükseltme \% 38.37, somut deneyimler elde etme \% 44.18, üretici kılma \% 51.16 kategorilerinde katılıyorum düzeyinde olduğu görülmektedir.

\section{Sonuç ve yorumlar}

Dijital hikâyelerin öğrenci görüşlerine göre eğitime katkı sağlayacağının tespit edildiği bu çalışmada öğrenciler; dijital hikâye kavramı ile ilgili olarak olumlu (\% 80.76) kategoride altı kod ve olumsuz kategoride (\% 19.23) ise iki kod altında toplanan görüş bildirmiştir. Dijital hikâye kavramı ile ilgili sonuçlara bakıldığında öğrencilerin her üç lisans seviyesinde de dijital-teknoloji-dijital ortam, ses/görüntü destekli anlatım şeklinde ifade edilebilecek şekilde dijital hikâye kavramını açıkladıkları görülmüştür. Benjamin (2012), "İnsanın bütün yaşamının hikâyelerinin malzemesi olduğu ve hikâyelerin kendini zamanla tüketmediğini, gücünü koruduğunu ve ylllar sonra bile harekete geçirebildiğini belirtmektedir" (Akt. Çıralı Sarıca, 22, 2019). Dijital hikâye kavramını öğrencilerin \% 43,58 oranında sanal ortamda daha önce var olan hikâyelerin yer alması şeklinde ifade etmeleri konu ile ilgili ayrıntılı bilgileri olmasa da kavramı oluşturan kelimelerin anlamından yola çıkarak fikir yürüttüklerini göstermektedir. "Dijital hikâyeler, hikâye anlatımının ses, görüntü vb. çoklu ortam araçlarıyla birleştirilmesi sonucu oluşturulan anlatımlardır” (Robin, 2006). Öğrencilerin \%14,10’unun dijital hikâye hakkında bilgisi olmadığını söylemesi kavramı oluşturan kelimelerden yola çıkarak da olsa bir düşünce geliştirmediklerini veya geliştirmek istemediklerini göstermektedir. Öğrencilerin \% 10,25 'i teknolojik ve yeni olgular, \% 8,97'si daha iyi anlama aracı, \% 3,84'ü kolaylık, faydalı vb. olarak dijital hikâye kavramını ifade etmişlerdir ve bu da öğrencilerin dijital hikâyeleri öğrenmeye katkısı olacak bir materyal olarak zihinlerinde canlandırdıklarını göstermektedir. Dijital hikâye kavramını \% 2,56'sı kendi sesiyle anlattığı kısa bir film şeklinde tanımlamışlar ve dijital hikâyeler hakkında tam bilgiyle sahip olduklarını bu şekilde göstermişlerdir. Dijital hikâyelere öğrencilerin \% 5,12'si olumsuz bakmıştır. Öğrencilerin yaklaşık \% 80’i ise dijital hikâye kavramı hakkında olumlu görüş bildirmişlerdir.

"Gerek sınıf ortamında işlenen derslerde gerekse derslere yardımcı olması için çeşitli platformlar (Youtube, facebook, blog vb.) aracılığı ile dijital hikâyeler kullanılmaktadır. Dijital hikâyeler bu özellikleriyle bir e-içerik olmasının yanında öğrenme nesnesi olarak da nitelendirilebilirler" (Yılmaz vd., 1633). Dijital hikâyelerin eğitim ve öğretim faaliyetlerinde kullanılabilirliği ile görüşlere öğrencilerin gözlerinden genel olarak bakıldığında \% 67,94'ünün evet cevabı vererek ve dijital hikâyelerin eğitim ve öğretimde kullanılmasını olumlu buldukları; öğrenim durumlarına göre ise ön lisans, lisans ve lisansüstü şeklindeki sıralamanın dijital hikâyelerin eğitim ve öğretim faaliyetlerinde kullanılabilirliğine bakışta da aynı olduğu anlaşılmıştır. Ön lisans seviyesinde \% 52,5, lisans seviyesinde \% 72,72 ve lisansüstü seviyesinde ise \% 100 oranında dijital hikâyelerin eğitimde kullanılmasının faydalı olacağı görüşü çalışmada görülmüştür. "Geleneksel anlatma yönteminden sıkılmış olan öğrencilerle yapılan dijital hikâye anlatma etkinlikleri sırasında öğrencilerin bir arada çalışıp fikir alışverişinde bulunarak sorunlarına çözüm bulması gerekecek, ortaya çıkan ürünlerini birbirlerine geribildirim vererek geliştireceklerdir" (Kocaman Karoğlu, 102). Dijital hikâyelerin eğitim ve öğretim faaliyetlerinde kullanmanın etkileri ile ilgili yapılan bir çalışmada Kearney (2009) ilköğretim öğretmeni adaylarının dijital öykülerin öğretmen adaylarının öğrenme yolculuklarını ilgi çekici şekillerde sunmalarına yardımcı olduğu ve kendi başına bir materyal hâlinde kullanılabileceği

\begin{tabular}{r|l} 
Adres & Address \\
RumeliDE Dil ve Edebiyat Arașturmaları Dergisi & RumeliDE
\end{tabular}

Osmanağa Mahallesi, Mürver Çiçeği Sokak, No:14/8 Osmanağa Mahallesi, Mürver Çiçeği Sokak, No:14/8

Kadıköy - İSTANBUL / TÜRKIYE 34714 Kadıköy - ISTANBUL / TURKEY 34714

e-posta: editor@rumelide.com e-mail: editor@rumelide.com,

tel: +90 505 7958124, +90 2167730616 phone: +90 505 7958124, +90 2167730616 
sonucuna ulaşmıştır. Kearney'in (2009) çalışmasında elde edilen sonuç ile bu çalışmada elde edilen sonuç birbiri ile tutarlılık göstermektedir. Pekmezci (2014) tarafından yapılan çalışmada da elde edilen sonuçlara paralel olarak bilişim teknolojileri destekli kısa hikâyelerin öğrencilerin akademik başarılarını artırdığı, derse yönelik daha olumlu tutum geliştirdikleri ve fene karşı öz yeterlik algılarının yükseldiği belirlenmiştir.

Bilişim teknolojilerinin dil gelişimini desteklediği (Chera ve Wood, 2003; Segers ve Verhoeven 2005; Tecen, 2018), çocukların ekranda yaptıklarını anlatma eğiliminde oldukları (Kartal ve Güven, 2006), dijital araçları ebeveynleriyle kullandıklarında daha etkili öğrenmeler gerçekleştirdikleri (Akkoyunlu, 1992, Özkılıç Kabul, 2019) yapılan çalışmalarda elde edilen bulgulardan bazılarıdır. Bilindiği gibi dil gelişimi bilişsel gelişmede çok önemli bir faktördür. Bilişsel gelişimde ortaya çıkacak olumlu sonuçlar bireyin kendisi için gerekli olan bütün becerilerine etki edecektir. Buradan hareketle dijital hikâyelerin öğretim faaliyetlerinde kullanılması başta bilişsel, duyuşsal ve fiziksel gelişmeleri de beraber getirecektir.

\section{Öneriler}

21. yüzyllın gereği olarak her öğretim seviyesinde dijital okuryazarlık becerilerinin geliştirilmesi için çalışmalar yapılmalıdır.

Dijital okuryazarlık becerilerinin geliştirilmesinde dijital hikâyeler elverişli birer araç olarak kullanılabilir.

Dijital hikâyeler her bilim dalında ve her öğretim seviyesinde öğrenmeyi kolaylaştıracak ve etkili hâle getirecek materyaller olarak kullanılabilir.

Dijital hikâyelerle ilgili olarak ön lisans, lisans ve lisansüstü seviyedeki öğrencilerin olumlu yaklaşımlarından yola çıkılarak etkili ders araç ve gereçleri üretilebilir.

Dijital hikâyeler yoluyla her öğretim seviyesindeki öğrencilerin kendilerini istedikleri şekilde ifade edebilecekleri ortamlar oluşturulabilir.

\section{Kaynaklar}

Akkoyunlu, B. (1992). İlköğretimin niteliğinin artırılmasında bilgisayarların yeri ve önemi. Hacettepe Üniversitesi Ĕ̆itim Fakültesi Dergisi, 8(8), 321-324.

Chera, P., Wood, C. (2003). Animated multimedia "talking books" can promotphonological awareness in children beginning to read. Learning and Instruction, 13, 33-52.

Çrralı Sarıca, H. (2019). Öğretmenlerin Dijital Hikâye Anlatımı Üzerinden Mesleki Kendini Anlayışları Ve Öğretmen Adaylarınca Almlanması. Hacettepe Üniversitesi Eğitim Bilimleri Enstitüsü Bilgisayar ve Öğretim Teknolojileri Eğitimi Ana Bilim Dalı, Ankara (Yayımlanmamış Doktora Tezi)

Kartal, G., \& Güven, D. (2006). Okul öncesi eğitimde bilgisayarın yeri ve rolü. Boğaziçi Üniversitesi Ĕ̆itim Dergisi, 23, 19-34.

Kearney, M. (2009). Investigating Digital Storytelling and Portfolios in Teacher Education. In G. Siemens \& C. Fulford (Eds.), Proceedings of ED-MEDIA 20o9--World Conference on Educational Multimedia, Hypermedia \& Telecommunications (pp. 1987-1996). Honolulu, HI, USA: Association for the Advancement of Computing in Education (AACE).

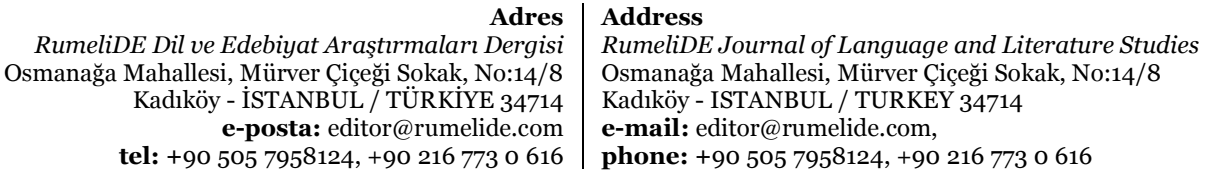

tel: +90 505 7958124, +90 2167730616

phone: +90 5057958124 , +90 216773 o 616 
Kearney, M. (2011) A learning design for student-generated digital storytelling, Learning, Media and Technology, 36:2, 169-188, DOI: 10.1080/17439884.2011.553623.

Kocaman-Karoğlu, A. (2015). Öğretim Sürecinde Hikâye Anlatmanın Teknolojiyle Değişen Doğası: Dijital Hikâye Anlatım. Eğitim Teknolojisi Kuram ve Uygulama, 5 (2) , 89-106. DOI: 10.17943/etku.29277.

Lambert, J., Hessler, B. (2013). The Work of Story: Capturing Lives, Creating Community. New York: Routledge.

McLellan, H. (2006). Digital Storytelling in Higher Education. Journal of Computing in Higher Education, 19 (1), 65-79.

Miles, M. B., \& Huberman, A. M. (1994). Qualitative data analysis: An expanded sourcebook. 2nd Edition. Thousand Oaks, CA: Sage.

Özkılıç Kabul, N. D. (2019). Üç yaş çocuklarda teknolojik alet kullanımının sosyal beceri, oyun becerisi ve dil gelişimi üzerindeki etkilerinin incelenmesi. Doktora tezi, Maltepe Üniversitesi Sosyal Bilimler Enstitüsü.

Pekmezci, S. (2014). Bilişim teknolojileri destekli kısa hikâyelerin öğrencilerin başarıları, özyeterlik algıları ve fene yönelik tutumlarına etkisi. Yayımlanmamış Yüksek Lisans Tezi, Pamukkale Üniversitesi Eğitim Bilimleri Enstitüsü.

Robin, B. (2006, March). The educational uses of digital storytelling. In Society for Information Technology \& Teacher Education International Conference (Vol. 2006, No. 1, pp. 709-716).

Russell, D. L. (2004). Literature for Children. (5th Edition), Pearson Education: USA-Boston.

Saban, A, Ersoy, A., (2017) Eğitimde Nitel Araştırma Desenleri. Anı.

Schank, R. C. (1995). Tell me A Story Narrative and Intelligence. Northwestern Universty Press, 255ss.

Segers, E., Verhoeven, L. (2005). Long-term effects of computer training of phonological awareness in kindergarten. Journal of Computer Assisted Learning, 21, 17-27.

Subaşı, M, Okumuş, K. (2017). Bir Araştırma Yöntemi Olarak Durum Çalışması. Atatürk Üniversitesi Sosyal Bilimler Enstitüsü Dergisi, 21 (2) , 419-426

Şimşek, Usluel, Çıralı Sarıca ve Tekeli, (2018). "Türkiye'de Eğitsel Bağlamda Dijital Hikâye Anlatımı Konusuna Eleştirel Bir Yaklaşım”. Eğitim Teknolojisi Kuram Ve Uygulama, Cilt:8 Sayı:1 Yll:2018.

Tecen, B. (2018). Okul öncesi dönem ses eğitiminde dijital oyun temelli destekleyici aktivitelerin çocukların sesli harfleri öğrenmelerine etkisi. Yüksek lisans tezi, Bahçeşehir Üniversitesi Eğitim Bilimleri Enstitüsü.

Yılmaz, Y., Üstündă̆, M. T., Güneş, E. (2017). Öğretim materyali olarak dijital hikâye geliştirme aşamalarının ve araçlarının incelenmesi. Abant İzzet Baysal Üniversitesi Ĕ̆itim Fakültesi Dergisi, 17 (3), 1621-1640.

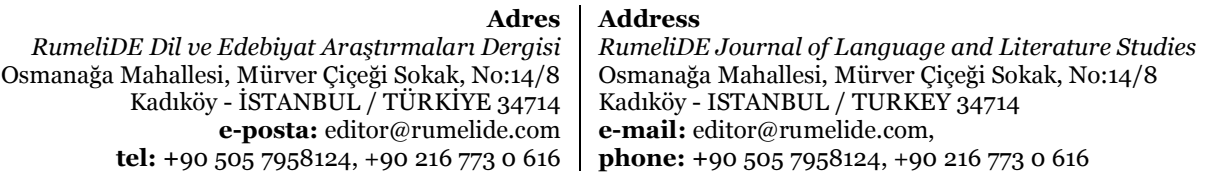

